
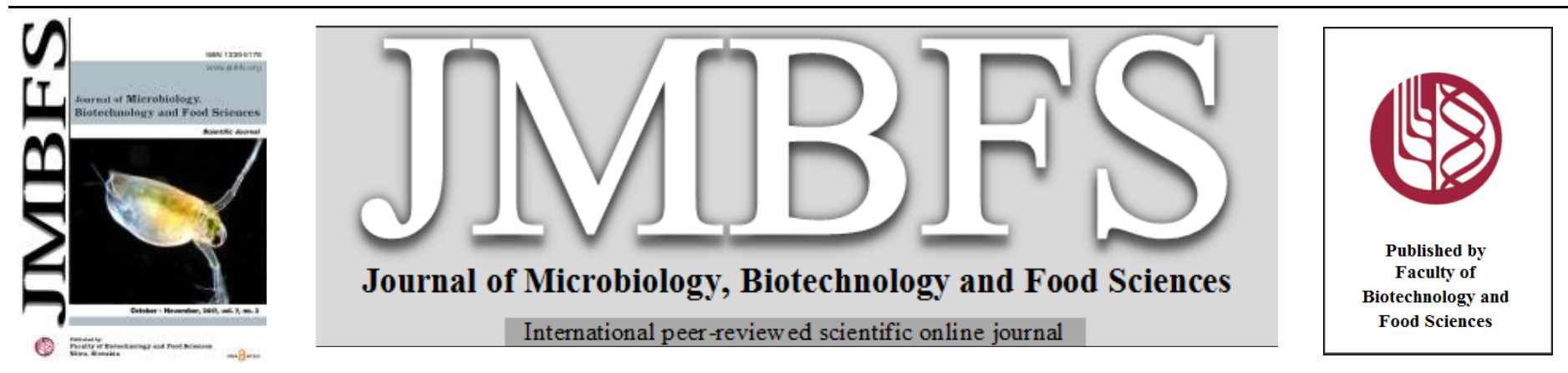

\title{
BY-PRODUCTS OF DATES: OPTIMIZATION OF THE EXTRACTION OF JUICE USING RESPONSE SURFACE METHODOLOGY AND ETHANOL PRODUCTION
}

\author{
Sofien Chniti ${ }^{1,2,3}$, Monia Jemni ${ }^{4}$, Imen Bentahar ${ }^{3}$, Mohammad Ali Shariati $^{5}$, Hayet Djelal ${ }^{1,2,6}$, Abdeltif Amrane ${ }^{2,6}$, Mnasser \\ Hassouna ${ }^{3}$
}

\begin{abstract}
$\operatorname{Address(es):~}$
${ }^{1}$ Ecole des Métiers de l’Environnement, Campus de Ker Lann, 35170 Bruz, France.

${ }^{2}$ Université de Rennes 1, ENSCR, CNRS, UMR 6226, Avenue du Général Leclerc, CS 50837, 35708 Rennes Cedex 7, France.

${ }^{3}$ Ecole Supérieure des Industries Alimentaires de Tunis, Université Carthage et sis Avenue de la République, B.P 77, 1054 Amilcar, Tunisie.

${ }^{4}$ Centre Régional de Recherche en Agriculture Oasienne de Degueche, Laboratoire de technologies de dattes, Tozeur, Tunisie.

${ }^{5}$ Research Department, LLC «Science \& Education», and Researcher, All Russian Research Institute of Phytopathology, Moscow Region, Russia.

${ }^{6}$ Université Européenne de Bretagne, 5 Bd Laennec, Rennes, France.
\end{abstract}

*Corresponding author: sofien.chniti@hotmail.fr

doi: 10.15414/jmbfs.2017.7.2.204-208

\section{ARTICLE INFO}

Received 24. 5. 2017

Revised 20. 7. 2017

Accepted 14. 9. 2017

Published 1. 10. 2017

Regular article

open $O$ access

\section{ABSTRACT}

The optimal extraction conditions were determined for by-product of date fruit by using the response surface design method. The obtained juice was used for the production of ethanol by fermentation of free cells of Saccharomyces cerevisiae. Optimal conditions for date juice extraction were found to be $80^{\circ} \mathrm{C}, 60 \mathrm{~min}, 1: 2$ dilution (fruit on water ratio) according to the result of response surface analysis (Equivalents glucose: 219 g.L $\mathrm{L}^{-1}$ ). Saccharomyces cerevisiae showed a preference for glucose over fructose and among the tested total sugar concentrations, namely 50,100, 174 and 358 g.L. $\mathrm{L}^{-1}, 174 \mathrm{~g} . \mathrm{L}^{-1}$ appeared to be the optimal amount, leading to $70 \mathrm{~g} . \mathrm{L}^{-1}$ ethanol concentration after $66 \mathrm{~h}$ of fermentation,; while an inhibitory effect of a high sugar content, $358 \mathrm{~g} . \mathrm{L}^{-1}$ of total sugars, namely about 2 $\mathrm{mol} / \mathrm{L}$ of monosaccharide like glucose or fructose was also shown. Overall, this study suggested that date juice can be utilized for ethanol production.

Keywords: by-product, optimal extraction, response surface analysis, fermentation, Saccharomyces cerevisiae, ethanol

\section{INTRODUCTION}

Date, the fruit of the date palm tree (Phoenix dactylifera $\mathrm{L}$. ), is one of the oldest fruit crops grown in arid areas of North Africa and Middle East. (Chandrasekaran and Bahkali, 2013).

Tunisia is the 9th word producer (FAOSTAT, 2015) and the first exporter of dates in value (Besbes et al., 2009). The date palm tree Phoenix dactylifera $\mathrm{L}$. constitutes the basis of economy for people living in Tunisian Sahara (Besbes $\boldsymbol{e t}$ al., 2009). Tunisian production has reached 120000 tons per year with the dominance of the "Deglet-Nour" variety constituting about $60 \%$ of the total production (Besbes et al., 2009) and (Kchaou et al., 2013). This production progress is unfortunately accompanied by a substantial increase of loss during storage, commercialization and conditioning process (Abbès et al., 2011). Date by-products, are not consumed because of their low quality (inadequate texture, microbes contamination and/or insect infestation).

Presently, very little use is made of these by-products and they are discarded or used in limited cases for animal feed (Abbès et al., 2011). Research into date byproducts has not been a true reflection of the importance and the potential of this crop, while dates are a rich source of some nutrients and sugars (70-80\%) such as glucose, fructose and sucrose (Al-Farsi et al., 2011; Elarem et al., 2008; Elleuch et al., 2008. Due to the high mineral and carbohydrate content of dates, juice has been utilized for the production of value added products, especially by fermentation.

Recently, there has been an increased attention in the field of bioenergy as world energy consumption has increased. Ethanol is a renewable energy with a high efficiency and a low environmental impact. Bioethanol can be obtained from a variety of feedstocks using cellulosic, starchy and sugar sources. These feedstocks include corn, sugar cane, bagasse, sugar beet, sorghum, barley, potatoes, wheat, wood and other biomass materials (Ibeto et al., 2011). Date's fruit can also be used for bioethanol production after sugar and nutriments extraction. One of the most expensive steps of bioethanol production from biomass is the pretreatment; so it is necessary to propose an easy process in accordance with economic and environmental aspects. In general, pretreatment technologies are divided into four major groups i.e. physical, chemical, physicochemical and biological. Although each extraction method has some advantages, one method cannot be the most relevant for all types of biomasses and products. For Date juice different methods were tested like soxhlet and solvent extraction (Louhichi et al., 2013). The energy consumed by the soxhlet technique was too important for an eco-friendly process; while the use of solvent extraction can present some risks. Otherwise enzymatic extraction gave good results but this process appeared too expensive for an industrial application (Chandrasekaran and Bahkali, 2013), therefore, it's necessary to optimize this step.

Response surface methodology (RSM) is a collection of statistical and mathematical techniques that has been successfully used for developing, improving and optimizing biochemical process (Chandrika and Freidoon, 2005; Lee et al., 2011; Luo, 2012). When many factors and interactions affect the desired response, RSM is an effective tool for optimizing the process (Cai $\boldsymbol{e t}$ al., 2007). Response surface methodology is often considered, since it allows determining the effect of factors on characteristic properties, the best optimal conditions of process and parameter interactions (Cai et al., 2007). Therefore, it is less laborious and more informational than other approaches (Wang $\boldsymbol{e t}$ al., 2007). Box-Behnken (BBD) is a type of response surface design. It is an independent quadratic design, since it does not contain an embedded factorial or fractional factorial design. In this design the treatment combinations are at the midpoints of edges of the process space and at the center. This design is rotatable (or near rotatable) and require 3 levels of each factor. It is more efficient and easier to arrange and interpret experiment in comparison with others. It is widely used in many researches (Zhu and Liu, 2013; Khajet, 2011; Sun et al., 2010; Zhao et al., 2009).

In this paper, RSM was employed for the extraction of sugars from by-products of dates "Deglet-Nour". The aim of this research was to develop an approach that would bring a better understanding of the combined effects of the key processing variables (extraction time, extraction temperature and ratio of raw material to water) on the desired response (Equivalents glucose on date juice), as well as to look for optimal conditions of sugars extraction from by-products of dates Secondly, the obtained juice was used to produce ethanol by fermentation of free 
cells of Saccharomyces cerevisiae, since it is traditionally used for alcohol beverage and bioethanol production; however, its performance during fermentation is compromised by the impact of sugar concentration.

\section{MATERIAL AND METHODS}

\section{Extraction and response surface analysis}

Byproduct dates of "Deglet-Nour" were supplied from Tunisian conditional unit of dates "ALKHALIJ". The fruits were pitted and cut in small pieces with a knife. Date pulp was added to hot distilled water at a weight to volume ratio of 1:2.5. The extraction was carried out on hot-plate at $85^{\circ} \mathrm{C}$ for $45 \mathrm{~min}$ (Acourene et al., 2011). The juice was filtered and centrifuged at $5000 \mathrm{rpm}$, at $4^{\circ} \mathrm{C}$ for 30 min and then the obtained supernatant was immediately concentrated to a tota sugar concentration of $720 \mathrm{~g} . \mathrm{L}^{-1}\left(72^{\circ} \mathrm{Brix}\right)$ on a hot plate at $80^{\circ} \mathrm{C}$ and then stored at $4^{\circ} \mathrm{C}$.

In order to extract sugar from dates, extraction conditions were determined by Box-Behnken response surface method (Box and Behnken, 1960) to examine the relationship between one or more response variables. The advantages of this method are a reduced number of samples and replicates (12 edges for three factors with three levels, for a total of 12 data points) and the center of the factor space (center point is replicated three times; totally $12+3=15$ data points) whereas the full factorial design has 27 data points ( 3 factors $\times 3$ levels $\times 3$ replicates). JMP 10, statistical software (Sas Institute, Cary, NC, USA) was used to design the best extraction conditions for date by giving the minimum and maximum values of determined parameters (Table 1).

Table 1 Box-Behnken response surface method design extraction parameters

\begin{tabular}{lll}
\hline Variable & Minimum & Maximum \\
\hline Temperature $\left({ }^{\circ} \mathrm{C}\right)$ & 70 & 90 \\
Time $(\min )$ & 30 & 90 \\
Dilution* & $1: 2$ & $1: 4$ \\
\hline
\end{tabular}

* dilution 1:2 means a mixture of $20 \mathrm{~g}$ of pulp dates and $40 \mathrm{~g}$ of water

\section{Microorganism and inoculum preparation}

The fermentative yeast, Saccharomyces cerevisiae 522D, was obtained from the culture collection of Pasteur Institute, Paris, France. Stock cultures were maintained on a gelified medium (g.. $\left.\mathrm{L}^{-1}\right)$ : glucose, 20; peptone, 10; yeast extract, 10; and agar, 10; and were stored at $4^{\circ} \mathrm{C}$. The inoculum preparation was previously described by Chniti et al. 2014).

\section{Ethanol production medium}

Date Syrup containing 50, 100, 174 and 358 g.L. $\mathrm{L}^{-1}$ was supplemented with minera culture medium as described previously by Chniti et al. 2014. The ethanol production medium (EPM) was transferred into a $500 \mathrm{~mL}$ bottle with a final working volume of $300 \mathrm{~mL}$ and was autoclaved at $120^{\circ} \mathrm{C}$ for $20 \mathrm{~min} . \mathrm{KOH} 1$ $\mathrm{mol} / \mathrm{L}$ was used to adjust the $\mathrm{pH}$ to 6 . Medium was sterilized by filtration on a 0.2 $\mu \mathrm{m}$ membrane (Sartorius, Goettingen, Germany).

\section{Fermentation processes}

The sterile EPM medium containing sugar concentration in the range of 50 to 358 g. $\mathrm{L}^{-1}$ was inoculated with Saccharomyces cerevisiae ( $200 \mu \mathrm{L}$ of inoculum). Batch fermentation was carried out in $500 \mathrm{~mL}$ bottle containing $300 \mathrm{~mL}$ of medium in an incubator shaker (New Brunswick, INNOVA 40, NJ, USA) at $28^{\circ} \mathrm{C}$ for $72 \mathrm{~h}$. All experiments were performed in duplicate and samples $(5 \mathrm{~mL})$ were taken from the culture at regular time intervals.

\section{Analytical methods}

The cell density of the fermentation broth was measured at $600 \mathrm{~nm}$ (A600) using a spectrophotometer (SECOMAM, Alès, France). The fermentation broth was centrifuged at $350 \mathrm{rad} / \mathrm{s}$ for $5 \mathrm{~min}$. The supernatant was used to analyse ethanol and residual sugars concentration by HPLC (Chniti et al., 2014). In addition, $\mathrm{NH}_{4} \mathrm{Cl}$ concentration was analysed by the Method of Mann, 1963. The total sugar content was expressed in equivalents of glucose (glucose + fructose $+1.05 \mathrm{x}$ sucrose) (Guigou et al., 2011).

\section{Statistical analysis}

All fermentation and date extractions were duplicated. In order to evaluate the significant differences between results, the Generalized Linear Model (GLM with $\mathrm{p}<0.05$ ) and Tukey's honestly significant differences (HSD) multiple comparison module within JMP statistical software package were used.

\section{RESULTS AND DISCUSSION}

\section{Date extract optimization}

Optimization was performed by using Box-Behnken response surface method in terms of temperature, extraction time and dilution (ratio of date to water).

\section{Effect of temperature on the extraction}

When the temperature of the extraction increased, the sugar concentration in the juice increased slightly during the 3-extraction times (Figure 1). For instance, when compared with 70 and $90^{\circ} \mathrm{C}$ extraction temperature at $1: 4$ dilution and for the same extraction time $(60 \mathrm{~min})$, the sugar concentration in the juice obtained at $90^{\circ} \mathrm{C}\left(126 \mathrm{~g} . \mathrm{L}^{-1}\right)$ was almost the same to that obtained at $70^{\circ} \mathrm{C}\left(122 \mathrm{~g} . \mathrm{L}^{-1}\right)$. However the temperature effect depends significantly upon the dilution, for instance, juice obtained at $70^{\circ} \mathrm{C}$ and at 60 min extraction were $18.8 \%$ and $33.6 \%$ for 1:4 and 1:2 dilution (Table 2). Therefore, the extraction temperature $*$ the dilution interaction were found to be statistically significant $(\mathrm{p}<0.05)$.

As can be seen from Figure 1, the residual sugars increased only slightly with the temperature. Based on these results, it can be deduced that the temperature did not play a significant part in the extraction of residual sugars from dates' fruit.

(a)

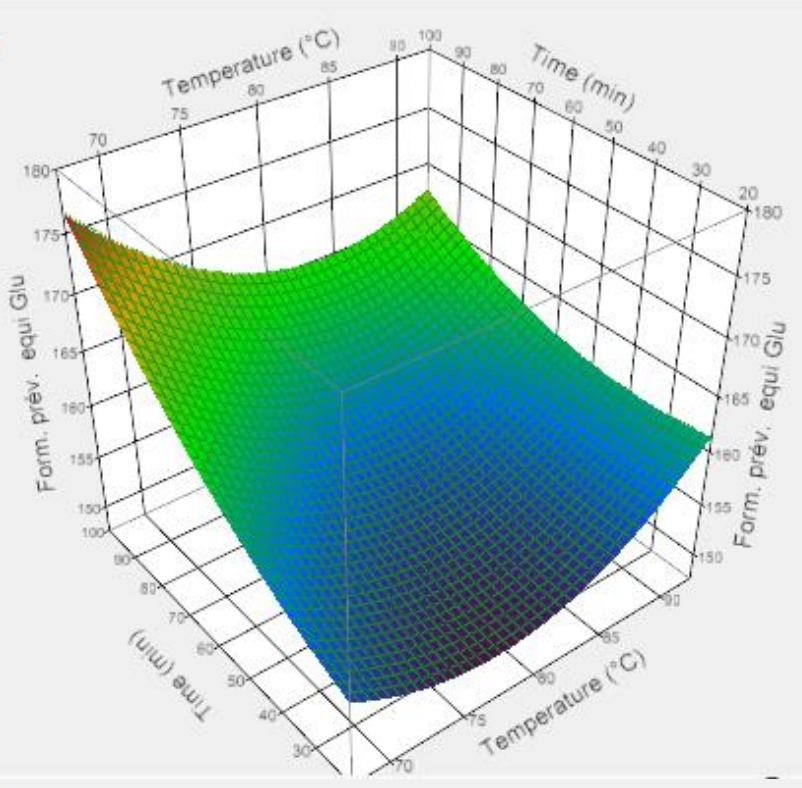

(b)

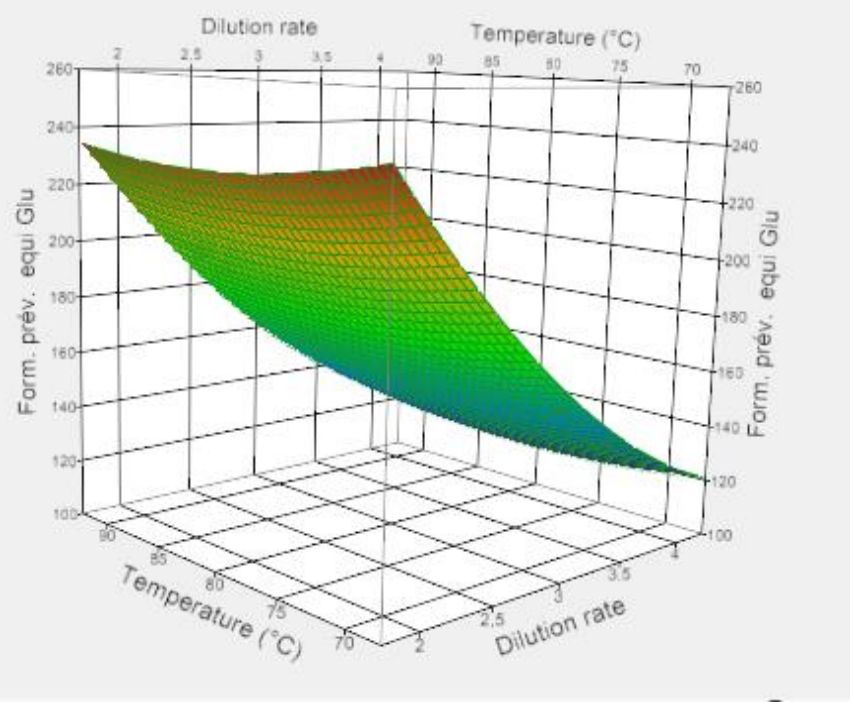


(c)

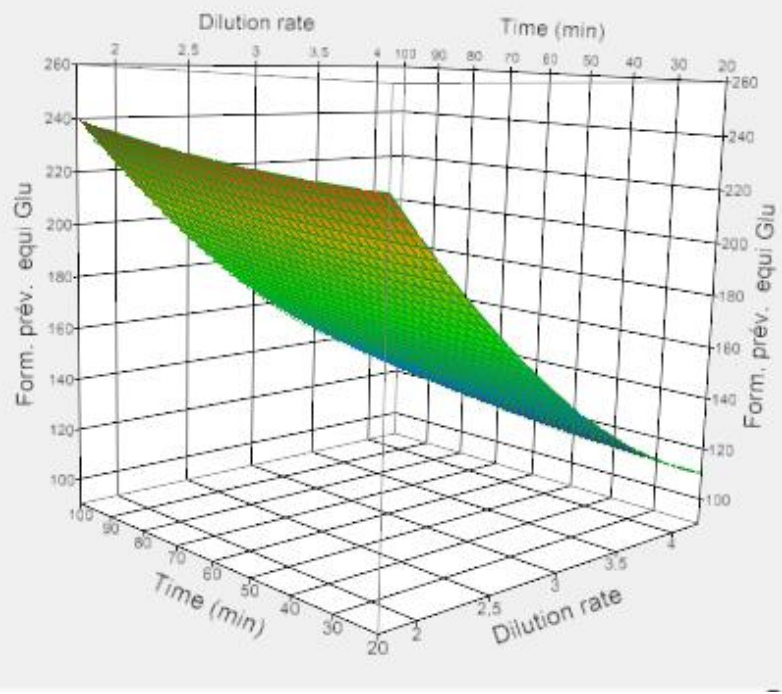

Figure 1 Surface plots of total sugar $\left(\mathrm{g} . \mathrm{L}^{-1}\right)$ for dates' extraction.

\section{Effect of the extraction time}

Extraction is a contact-equilibrium process. When the soluble solids in the juice reach equilibrium, there is no diffusion of soluble solids from the raw materia into the juice. Fig 1 showed that extraction time was not effective by itself, but also directly depends upon dilution and temperature. While the extraction time was at a low level, the effect of temperature on the response was insignificant (Figure 1a). When the dilution was kept low, the amount of soluble solids in the juice was highly independent of time (Figure 1c). According to the results, the extracted amount of sugars was significant $(\mathrm{p}<0.05)$, and was affected by the extraction time and the dilution (Table 2).

Table 2 Results of dates' extraction obtained by the response surface method

\begin{tabular}{lllll}
$\begin{array}{l}\text { Sample } \\
\mathrm{N}^{\circ}\end{array}$ & $\begin{array}{l}\text { Temperature } \\
\left({ }^{\circ} \mathrm{C}\right)\end{array}$ & Time $(\mathrm{min})$ & Dilution & $\begin{array}{l}\text { Sugar Amount of } \\
\text { the juice }\left(\mathrm{g} . \mathrm{L}^{-1}\right)\end{array}$ \\
\hline 1 & 80 & 60 & $1: 3$ & 156 \\
2 & 90 & 30 & $1: 3$ & 154 \\
3 & 70 & 90 & $1: 3$ & 174 \\
4 & 80 & 90 & $1: 2$ & 216 \\
5 & 90 & 60 & $1: 2$ & 218 \\
6 & 90 & 60 & $1: 4$ & 126 \\
7 & 80 & 60 & $1: 3$ & 156 \\
8 & 70 & 60 & $1: 4$ & 122 \\
9 & 80 & 30 & $1: 2$ & 212 \\
10 & 80 & 60 & $1: 3$ & 156 \\
11 & 80 & 30 & $1: 4$ & 120 \\
12 & 90 & 90 & $1: 3$ & 156 \\
13 & 70 & 60 & $1: 2$ & 218 \\
14 & 70 & 30 & $1: 3$ & 154 \\
15 & 80 & 90 & $1: 4$ & 126 \\
\hline
\end{tabular}

\section{Effect of the dilution on the extraction}

Sugar concentration in the juice was the lowest when the largest dilution was considered (Table 2). It was also observed that the sugar concentration reached equilibrium level depending on the temperature and the time. It could be seen from Fig. 1 that the residual sugar concentration decreased gradually with increasing dilution. In other words, a low dilution decreased the time needed to reach equilibrium (Table 2). The lowest sugar concentration (120 g.. $\left.\mathrm{L}^{-1}\right)$ was obtained from the $1: 4$ dilution at $80^{\circ} \mathrm{C}$ and $30 \mathrm{~min}$. In contrast, the highest sugar concentration was obtained from the $1: 2$ dilution at $90^{\circ} \mathrm{C}$ and $60 \mathrm{~min}$. These data showed therefore that the dilution was among the major extraction parameters. As shown by the model (Figure 1), the concentration of residual sugars in the juice showed a maximum at 1:2 dilution $(217 \mathrm{~g} / \mathrm{L})$.

\section{Response surface modeling}

A full quadratic response surface model was developed. Variables used in the model were temperature $\left({ }^{\circ} \mathrm{C}\right)$, time $(\mathrm{min})$ and dilution $(\mathrm{w} / \mathrm{v})$. The response surface model was generated using JMP with uncoded units and the following regression equation was obtained.

Y : Residual sugar concentration in dates' juice
$\mathrm{Y}=\beta 0+\beta 1 \mathrm{~T}+\beta 2 \mathrm{t}+\beta 3 \mathrm{D}+\beta 22 \mathrm{t} 2+\beta 12 \mathrm{Tt}+\beta 13 \mathrm{TD}+\beta 23 \mathrm{tD}+\varepsilon$ Where, $\varepsilon=$ Error and $\beta 0, \beta 1, \beta 2, \beta 3, \beta 22, \beta 12, \beta 13$, and $\beta 23$ are coefficients (Table 3).

$\mathrm{T} 2$, $\mathrm{t} 2$ and $\mathrm{D} 2$ terms were removed from the model because they were not significant ( $\mathrm{p}<0.05)$. An R2 value (coefficient of determination) of 0.98 was obtained, which shows that $95 \%$ of the samples variation was taken into account by the model. It showed that extraction time $(\mathrm{t})$ and dilution rate were significant $(\mathrm{p}<0.05)$ (Table 3).

The model predicted that the best extraction conditions were $80^{\circ} \mathrm{C}, 60 \mathrm{~min}$ and 1:2 dilution, leading to 219 g. $\mathrm{L}^{-1}$ sugar concentration. For given conditions, when the dilution increased, the equilibrium point of the juice also increased. It was also previously reported that the final sugar concentration of dates' extract produced in hatch system was directly linked to temperature and time (Turhan $\boldsymbol{e}$ al., 2006). Application of high temperatures showed higher rates of soluble solids in the juice which contained more sugar; temperatures such as $80-90^{\circ} \mathrm{C}$ may be applied to obtain high sugar concentrations (Berthels et al., 2004). Based on the optimal conditions obtained, it can be concluded that there was no need for the highest temperature, the longest time and the largest dilution which means less waste of energy, time and materials.

\section{Verification of the models}

The suitability of the model equation for predicting the optimum response values was tested by using the selected optimal conditions. The maximum predicted concentration and experimental concentration of Equi Glucose were given in Table 4. Additional experimental by using the predicted optimum condition for syrup extraction were carried out: extraction temperature $80^{\circ} \mathrm{C}$, extraction time of 60 min, ratio of raw material to water 1:2, and the model predicted a maximum response of 219 g. $\mathrm{L}^{-1}$. To ensure the predicted result was not biased toward the practical value, experiment rechecking was performed by using these modified optimal conditions: extraction time of $60 \mathrm{~min}$, extraction temperature $80^{\circ} \mathrm{C}$, ratio of material to water 1:2. A mean value of $218.4 \pm 1.2 \mathrm{~g} . \mathrm{L}^{-1}(\mathrm{n}=3)$ was gamed, obtained from real experiments, demonstrated the validation of RSM model. The result of analysis confirmed that the response model was adequate for reflecting the expected optimization, and the model was satisfactory and accurate

\section{Fermentation Kinetics}

To investigate the influence of initial sugar concentration on end-product formation, S. cerevisiae was cultivated with Date juice at various substrate concentrations.

\section{Yeast growth}

The profile of cell growth is presented in Figure 2. Until 174 g.L $\mathrm{L}^{-1}$ cell growth ceased after $48 \mathrm{~h}$ culture. The viable cell numbers reached a maximum OD value at $600 \mathrm{~nm}$ of 14 for 100 and $174 \mathrm{~g} . \mathrm{L}^{-1}$, and around $10 \mathrm{OD}$ value for $50 \mathrm{~g} . \mathrm{L}^{-1}$, while an almost total absence of growth was observed for $358 \mathrm{~g} . \mathrm{L}^{-1}$, showing the inhibitory effect of a high sugar content, $358 \mathrm{~g} . \mathrm{L}^{-1}$ of total sugars, namely about 2 mol. $\mathrm{L}^{-1}$ of monosaccharide like glucose or fructose; at such high sugar content, only osmotolerant yeasts can grow (Passoth et al., 2006; Leandro et al., 2011)

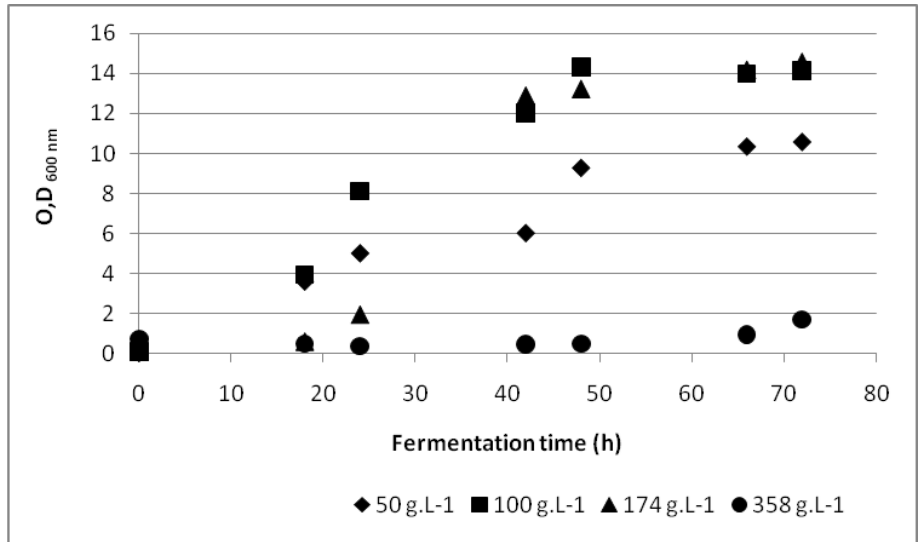

Figure 2 Cell density (OD $600 \mathrm{~nm}$ ) in media containing 50, 100, 174 and 358 g. $\mathrm{L}^{-1}$ sugars.

\section{Sugar consumption}

Dates juice contains almost equal amounts of glucose and fructose. The data clearly show that, for 50, 100 and 174 g.L. ${ }^{-1}$, sugars were almost completely fermented by S. cerevisiae (Figures 3a-c), which showed a preference for glucose over fructose; although it was shown that fructose can be used concomitantly with glucose (Berthels et al., 2008). Glucose and fructose are transported by the same carriers in S. cerevisiae (Berthels et al., 2008; Rogers et al.,1979). 
Structural analysis of sucrose shows a $\beta-1,2$ bond, which is cleaved by the enzyme invertase ( $\beta$-D-fructofuramoside fructohydrolase, EC.3.2.1.26). It is known that the yeast Saccharomyces cerevisiae produces intra and extracellular invertase.
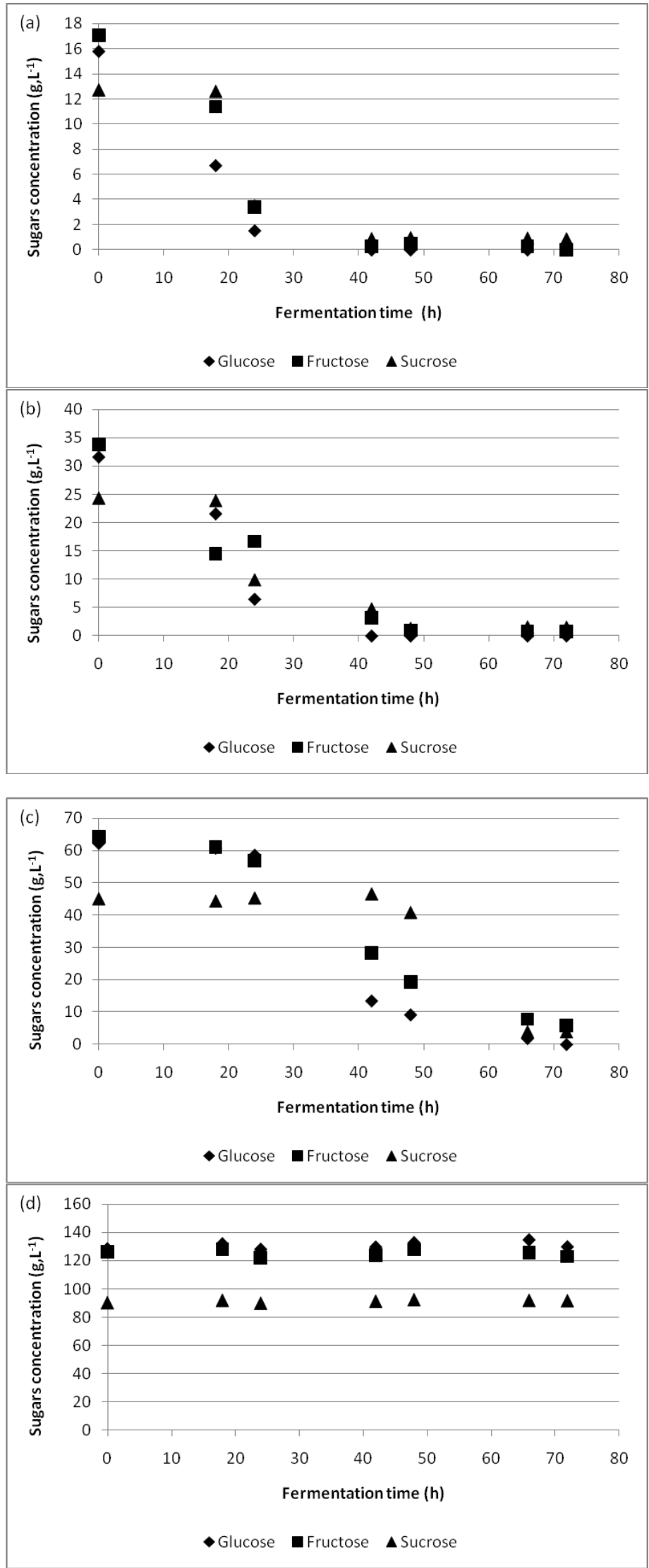

Figure 3 Sugar consumption during batch fermentation at initial sugar concentrations of 50 g.L - $^{-1}$ (a), 100 g.L $L^{-1}$ (b), 174 g.L - $^{-1}$ (c), 358 g.L L $^{-1}$ (d)

In close linking with growth (Figure 2), sugars consumption appeared almost negligible for 358 g.L $L^{-1}$ (Figure 3d), confirming that S. cerevisiae could not tolerate such high sugar content. This result appears in agreement with Rogers et al., 1979 and Chniti et al., 2014, which showed that at high glucose concentration yield of ethanol production by $S$. cerevisiae remained almost unaffected by initial glucose concentration up to approximately $20 \%$ and declined beyond that.

\section{Ethanol production}

Ethanol (Figure 4) production increased with the increase of sugar concentration up to 174 g.L. L $^{-1}$, while no production was observed for 358 g.L. L $^{-1}$ (Figure 5), in agreement with the absence of growth (Figure 2). Ethanol production increased with the sugar content until 62.9 g.L. ${ }^{-1}$ (Figure 4) produced for 174 g.L. ${ }^{-1}$, after 66 $\mathrm{h}$ of fermentation. Similar results were found by Laluce et al., 2009.

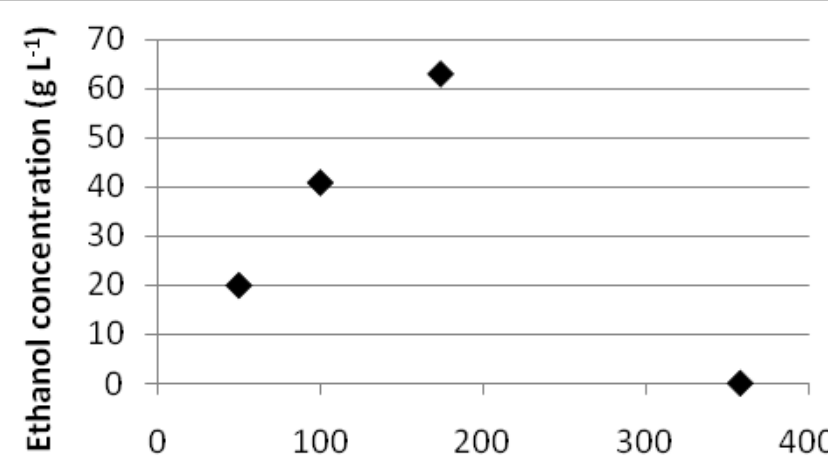

Sugar concentration $\left(\mathrm{g} \mathrm{L}^{-1}\right)$

Figure 4 Effect of initial sugar concentration on ethanol production by Saccharomyces cerevisiae.

Up to 174 g.L. ${ }^{-1}$, Table 4 shows that S. cerevisiae has consumed more than $90 \%$ sugars after $72 \mathrm{~h}$ of fermentation. For 50 and 100 g.L. $\mathrm{L}^{-1}$ initial sugar amount, the ethanol yield $\left(\mathrm{Y}_{\text {Ethanol/Glu }}\right)$ reached $43 \%$ and $45 \%$ respectively, after $72 \mathrm{~h}$, while $38 \%$ yield was observed for 174 g.L $\mathrm{L}^{-1}$. High initial substrate concentration may inhibit substrate utilization and decrease product yields.

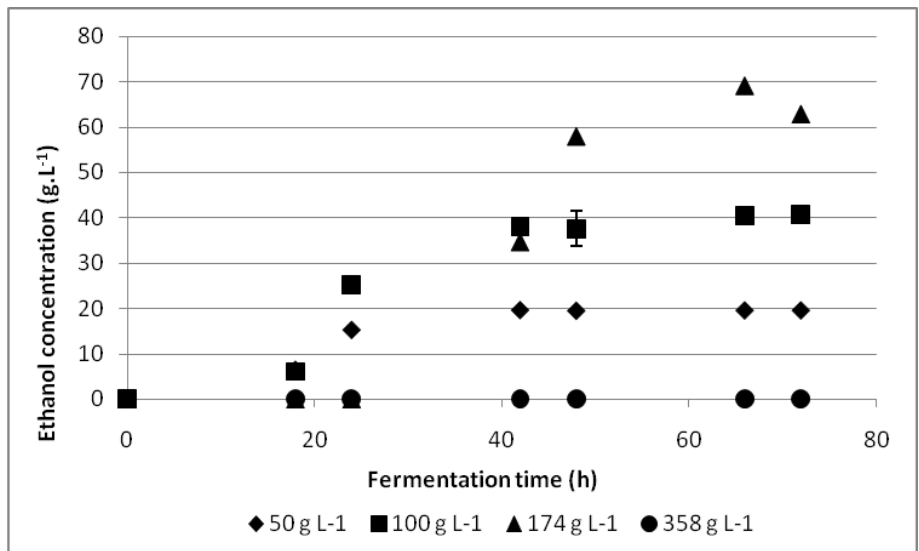

Figure 5 Ethanol production during batch fermentation by Saccharomyces cerevisiae on dates' juice.

A maximum ethanol productivity of $1.1 \mathrm{~g} . \mathrm{L}^{-1} \cdot \mathrm{h}^{-1}\left(\mathrm{Q}_{\text {Ethanol }}\right)$ was obtained for 174 g..$^{-1}$, at the end of fermentation (72 h). For the highest sugar content $\left(358\right.$ g.. $\left.\mathrm{L}^{-1}\right)$ yield as well as productivity appeared negligible, several studies have reported that high substrate concentration inhibit growth and fermentation of yeasts in industrial ethanol production as the result of high osmotic pressure (Guigou $\boldsymbol{e t}$ al., 2011). Ethanol productions increased from 20 to $63 \mathrm{~g} . \mathrm{L}^{-1}$ for an increase in the sugar amount from 50 to 174 g.L $\mathrm{L}^{-1}$. A low dilution represents an economy of equipment and process costs (e.g distillation costs), which appears appropriate for an industrial purpose.

\section{CONCLUSION}

The various examined parameters (temperature, extraction time and dilution) involved in hot water extraction of dates' juice showed that all these variables markedly affect the total sugars concentration; it was related to the extraction conditions by using second order polynomials. The optimal conditions for sugar extraction were found to be a solid:liquid ratio 1:2, $60 \mathrm{~min}$ time extraction and $80^{\circ} \mathrm{C}$, leading to a sugar concentration of 219 g. $\mathrm{L}^{-1}$. Optimal ethanol concentration and yield were obtained for 174 g.L $\mathrm{L}^{-1}$. Results of alcohol 
fermentation showed that date juice can be a good feedstock for ethanol production by $S$. cerevisiae in batch fermentation after pretreatment without utilization of chemicals materials. However, an economic study is necessary to evaluate the energy input for pretreatment step and the total yield of bioethanol production.

Acknowledgments: The author is thankful to his MS and $\mathrm{PhD}$ students to assist for this research work in the field as well as in the laboratory.

\section{REFERENCES}

Abbès, F., Bouaziz, M. A., Blecker, C., Masmoudi, M., Attia, H., \& Besbes, S. (2011). Date syrup: Effect of hydrolytic enzymes (pectinase/cellulase) on physicochemical characteristics, Sensory and Functional Properties. LWT Food Sci Technol, 44, 1827-1834.http://doi.org/10.1016/i.lwt.2011.03.020

Acourene, S., Djafri, K., Ammouche, A., Amourache, L., Djidda, A., Tama, M. \& Taleb, B. (2011). Utilization of date wastes as substrate for the production of baker's yeast and citric acid. Biotechnol, 10, 3845.http://doi.org/10.3923/biotech.2011.488.497

Al-Farsi, M., Alasalvar, C., Al-Abid, M., Al-Shoaily, K., Al-Amry, M., \& AlRawahy, F. (2011). Compositional and functional characteristics of dates, syrups, and their by-products. Food Chem, 104, 943 947.http://doi.org/10.1016/j.foodchem.2006.12.051

Besbes, S., Drira, L., Blecker, C., Deroanne C., \& Attia, H. (2008). Adding value to hard date (Phoenix dactylifera L.): Compositional, functional and sensory characteristics of date jam. Food Chem, 112, 406411.http://doi.org/10.1016/i.foodchem.2008.05.093

Berthels, N. J., Otero, R. R. C., Bauer, F. F., Thevelein. J. M., \& Pretorious, I. S. (2004). Discrepancy in glucose and fructose utilization during fermentation by Saccharomyces cerevisiae wine yeast strains. FEMS Yeast Research, 4, $683-$ 689.http://doi.org/10.1016/j.femsyr.2004.02.005

Berthels, N.J., Otero, R. R. C., Bauer, F. F., Thevelein, J. M., \& Pretorious, I. S (2008). Correlation between glucose/Fructose discrepancy and hexokinase kinetic properties in different Saccharomyces cerevisiae wine yeast strains. Appl Microbiol Biot, 4, 1083-1093.http://doi.org/10.1007/s00253-007-1231-2

Box, G.E.P. \& Behnken, D. W. (1960). Some new three level designs for the study of quantitative variables. Technometrics, 2, 455475.http://doi.org/10.2307/1266454

Cai, W.R., Gu, X. H., \& Tang, J. (2007). Extraction purification and characterization of the polysaccharides from Opuntia milipa alta. Carbohyd Polym, 71, 403-410.http://doi.org/10.1016/j.carbpol.2007.06.008

Chandrasekaran, M. \& Bahkali, A. (2013). Valorization of date palm ((Phoenix dactylifera) fruit processing by-products and wastes using bioprocess technology. $\begin{array}{llll}\text { Saudi } & \text { B } & \text { Biological } & \text { Sciences, }\end{array}$ 120.http://doi.org/10.1016/j.sjbs.2012.12.004

Chandrika, L.P. \& Fereidoon, S. (2005). Optimization of extraction of phenol compounds from wheat using response surface methodology. Food Chem, 93, 47-56.http://doi.org/10.1016/j.foodchem.2004.08.050

Chniti, S., Djelal, H., Hassouna, M., \& Amrane, A. (2014). Residue of dates from the food industry as a new cheap feedstock for ethanol production. Biomass Bioenerg, 69, 66-70.http://doi.org/10.1016/j.biombioe.2014.07.011

Elarem, A.G., Flamini, G., Emna, B. S., Issaoui, M., Zeyene, N., Ferchichi, A. Hammami, M., Helal-Ahmed, N., \& Achour, L. (2011). Chemical and aroma volatile compositions of date palm (Phoenix dactylifera L.) fruits at three $\begin{array}{lllll}\text { maturation } & \text { stages. } & \text { Food } & \text { Chem, } & 127,\end{array}$ 1754.http://doi.org/10.1016/j.foodchem.2011.02.051

Elleuch, M., Besbes, S., Roiseaux, O., Blecker, C., Deroanne, C., Drira, N., \& Attia, H. (2008). Date flesh: Chemical composition and characterisatics of the dietary fibre. Food Chem, 111, 676 682.http://doi.org/10.1016/j.foodchem.2008.04.036

FAOSTAT (2015) http://faostat.fao.org/site/339/default.aspx. accessed on 10.10 . Guigou, M., Lareo, C., Perez, L. V., \& Luberas, M. E. (2011). Bioethanol production from sweet sorghum: Evaluation of post-harvest treatments on sugar extraction and fermentation. Biomass Bioenerg, 35, 3058 3062.http://doi.org/10.1016/j.biombioe.2011.04.028

Ibeto, C. N., Ofoefule, A. U., \& Agbo, K. E. (2011). A global overview of biomass potentials for bioethanol production: A renewable alternative fuel. Trends Appl Sci Research, 6, 410-425.http://doi.org/ 10.3923/tasr.2011.410.425

Kchaou, W., Abbes, F., Blecker, C., Attia, H., \& Besbes, S. (2013). Effects of extraction solvents on phenolic contents and antioxidant activities of Tunisian date varieties (Phoenix dactylifera). Ind Crop Prod, 45, 262 269.http://doi.org/10.1016/j.indcrop.2012.12.028

Khajeh, M. (2011). Response surface modeling of lead pre-concentration from food samples by miniaturized homogenous liquid-liquid solvent extraction: Box$\begin{array}{llll}\text { behnken design. Food } & \text { Chem, }\end{array}$ 1838.http://doi.org/10.1016/j.foodchem.2011.05.123

Laluce, C., Tognolli, T. O., DeOliveira, K. F., Souza, C. S., \& Morais, M. R. (2009). Optimization of temperature, sugar concentration, and inoculums size to maximize ethanol production without significant decrease in yeast cell viability.
Appl Microbiol Biotechnol, 83, 627-637.http://doi.org/10.1007/s00253-009-1885

Leandro, M. J., Sychrova, H., Prista, C., \& Loureiro-Dias, M. C. (2011). The osmotolerant fructophilic yeast Zygosaccharomyces rouxii. Microbiology, 157, 601-608.http://doi.org/10.1099/mic.0.044446-0

Lee, W.C., Yusof, S., \& Hamid, N. S. A. (2011). Optimization conditions foe hot water extraction of banana juice using response surface methodology (RSM). $J$ Food Eng, 75, 473-479.http://doi.org/10.1016/j.jfoodeng.2005.04.062 Louhichi, B., Belgaid, J., Benamor, H., \& Hajji, N. (2013). Production of bioethanol from three varieties of dates. Renew energ, 51, 170174.http://doi.org/10.1016/j.renene.2012.07.028

Luo, D. (2012). Optimization of total polysaccharide extraction from Discorea nipponica Malikino using response surface methodology and uniform design. Carbohyd Polym, 90, 284-288.http://doi.org/ 10.1016/j.carbpol.2012.05.036

Mann, L.T. (2012). Spectrophotometric determination of nitrogen in total microkjeldhal digests. Anal Chem, 35, 2180-2182.http://doi.org/10.1021/ac60206a056

Masmoudi, M., Besbes, S., Chaabouni, M., Robert, C., Paquot, M., Blecker, C., \& Attia, H. (2008). Optimization of pectin extraction from lemon by-product with acidified date juice using response surface methodology. Carbohyd polym 74, 185-192.http://doi.org/10.1016/i.carbpol.2008.02.003

Passoth, V., Fredlund, E., Druvefois, U. A., \& Schnürer, J. (2006) Biotechnology, physiology and genetics of the yeast Pichia anomala. FEMS yeast Reasearch, 6, 3-11.http://doi.org/10.1111/j.1567-1364.2005.00004.X

Rogers, P. L., Lee, K. J., \& Tribe, D. E. (1979). Kinetics of alcohol production by Zymomonas mobilis at high sugar concentrations. Biotechnol Lett, 1, 165170.http://doi.org/10.1007/BF01388142

Sun, Y. and Liu, J., \& Kennedy, J. F. (2010). Application of response surface methodology for optimization of polysaccharides production parameters from the roots of Codonopsis pilosula by a contral composite design. Carbohyd Polym, 80 949-953.http://doi.org/10.1016/i.carbpol.2010.01.011

Turhan, I., Tetik, N., Aksu, M., Karhan, M., \& Certel, M. (2006). Liquid-solid extraction of soluble solids and total phenolic compounds of carob bean (Ceratonia siliqua L.). J Food Process Eng, 29, 498 507.http://doi.org/10.1111/j.1745-4530.2006.00078.x

Wang, Z. J., Luo, D. H., \& Cai, E. N. (2007). Optimization of polysaccharides extraction from Gynostemma pentaphyllum Makino using uniform design Carbohyd Polym, 69, 311-317.http://doi.org/10.1016/j.carbpol.2006.10.013

Zhao, H., Wang, J., \& Lu, Z. (2009). Optimization of process parameter of the Pholiota squarrosa extra cellular polysaccharide by Box-Behnken statistica design. Carbohyd Polym, 677 680.http://doi.org/10.1016/j.carbpol.2009.02.013

Zhu, C. \& Liu, X. (2013). Optimization of extraction process of crude polysaccharides from Pomegranate peel by response surface methodology. Carbohyd Polym, 92, 1197-1202.http://doi.org/10.1016/j.carbpol.2012.10.073 